\title{
GLOSA DO WYROKU NACZELNEGO SĄDU ADMINISTRACYJNEGO Z DNIA 15 MAJA 2012 R., SYGN. II OSK 356/12
}

\begin{abstract}
TEZY
(...) Należy podkreślić, że w świetle art. 201 ust. 1 p.o.ś. pozwolenia zintegrowanego $\mathrm{w}$ odróżnieniu od pozwolenia na wprowadzanie gazów i pyłów do powietrza, wymaga prowadzenie instalacji, której działalność z powodu rodzaju i skali prowadzonej w niej działalności, może powodować znaczne zanieczyszczenia nie tylko poszczególnych elementów przyrodniczych, lecz nawet środowiska jako całości, biorąc pod uwagę $\mathrm{w}$ szczególności rozmiar i skalę prowadzonej w danej instalacji działalności. Ponadto, nie pozwala to $\mathrm{z}$ tej przyczyny uznać, że należy opłatę za korzystanie ze środowiska - za okres, w którym nawet z przyczyn leżących po stronie organu, jeżeli upłynął już termin ważności poprzedniego pozwolenia - lecz właściwy organ nie stwierdził

* Doktor nauk prawnych, adiunkt w Katedrze Prawa Ochrony Środowiska, Wydział Prawa i Administracji, Uniwersytet Mikołaja Kopernika.
\end{abstract}


jeszcze jego wygaśnięcia - zaś nowe pozwolenie nie zostało jeszcze wydane - uiszczać w wysokości takiej opłaty jak w okresie ważności dotychczasowego pozwolenia [na wprowadzanie gazów i pyłów do powietrza].

I. Stan faktyczny w przedmiotowej sprawie przedstawiał się w sposób następujący. Marszałek Województwa Świętokrzyskiego decyzją z 2009 r. ustalił dla Ceramiki Budowlanej Sp. z o.o. w Krakowie opłatę za korzystanie ze środowiska (wprowadzanie gazów i pyłów do powietrza) za I półrocze 2008 r., w wysokości 19565,00 zł stanowiącej różnicę między opłatą należną, a wynikającą ze złożonego przez spółkę wykazu. Wydanie tej decyzji wymiarowej wynikało z ustalenia przez organ, iż spółka w I półroczu 2008 r. korzystała ze środowiska eksploatując instalacje bez wymaganych pozwoleń zintegrowanych, co zgodnie z art. 276 uPoś $^{1}$ oznaczało obowiązek poniesienia opłaty podwyższonej za korzystanie ze środowiska.

Spółka zaskarżyła tę decyzję organu I instancji do organu odwoławczego (SKO w Kielcach), który utrzymał w ją mocy. W ocenie organu odwoławczego nie ulegało wątpliwości, że w I półroczu 2008 r. spółka eksploatowała instalacje bez wymaganych pozwoleń zintegrowanych. Podnoszoną przez spółkę okoliczność zmiany prawa - to jest wprowadzenia obowiązku uzyskania dla instalacji, eksploatowanych dotąd zgodnie z pozwoleniem na emisję gazów i pyłów do powietrza, nowego rodzaju pozwolenia - zintegrowanego, organ odwoławczy poddał szczegółowej analizie. Organ rozróżnił następujące okoliczności: sytuację pierwszą - brak pierwszego pozwolenia zintegrowanego przed rozpoczęciem eksploatacji instalacji, oraz sytuację drugą - okres przejściowy do uzyskania pierwszego pozwolenia zintegrowanego dla instalacji już eksploatowanej na podstawie pozwolenia sektorowego. $\mathrm{W}$ tym drugim przypadku organ odwoławczy ustalił, że okres przejściowy do uzyskania pozwolenia zintegrowanego dla instalacji skarżącej spółki upłynął najpóźniej w dniu 31 grudnia 20006 r., co wynikało z usta-

1 Ustawa z dnia 27 kwietnia 2001 r. Prawo ochrony środowiska, tj. Dz. U. z 2008 r. Nr 25, poz. 150 ze zm.; dalej cyt.: uPoś. 
wy z dnia 27 lipca 2001 r. o wprowadzeniu ustawy - Prawo ochrony środowiska, ustawy o odpadach oraz o zmianie niektórych ustaw ${ }^{2}$, a zwłaszcza z wydanego na podstawie art. 19 tej ustawy rozporządzenia Ministra Środowiska z dnia 26 września 2003 r. w sprawie późniejszych terminów do uzyskania pozwolenia zintegrowanego ${ }^{3}$.

W rezultacie organ odwoławczy podzielił stanowisko organu I instancji, że przedmiotowe instalacje były eksploatowane w I półroczu 2008 r. bez wymaganych pozwoleń zintegrowanych. Jednocześnie zgodził się również z oceną organu I instancji, że fakt nieuzyskania przez skarżącą spółkę pozwoleń zintegrowanych w terminie do dnia 31 grudnia 2006 r. nie wynikał z wyłącznej winy organów pozwoleniowych, o czym świadczyły chociażby daty złożenia wniosków o wydanie odnośnych pozwoleń (29 grudnia 2006 r.). Organ odwoławczy przyznał, że w myśl art. 209 ust. 2 uPoś jeżeli pozwolenie ma objąć instalację po raz pierwszy lub ma objąć instalację po istotnej zmianie, wydanie pozwolenia powinno nastapić w ciągu 6 miesięcy od dnia złożenia wniosku. Spółka natomiast uzyskała większość pozwoleń dopiero w II połowie 2008 roku, a więc rzeczywiście po przekroczeniu przez organy pozwoleniowe wskazanego okresu 6 miesięcy.

Spółka wniosła na decyzję SKO skargę do WSA w Kielcach. W swojej skardze spółka przedstawiła argumenty kwestionujące przesłankę „braku pozwolenia” warunkującą powstanie obowiązku poniesienia opłaty podwyższonej za korzystanie ze środowiska. W ocenie skarżącej spółki posiadając w I półroczu 2008 r. ważne pozwolenia sektorowe na odprowadzenie pyłów i gazów dla eksploatowanych instalacji, których suma odpowiadała pozwoleniom zintegrowanym, spółka nie posiadała jedynie jednolitego dokumentu pozwolenia zintegrowanego.

WSA rozpatrując sprawę podzielił ocenę organu odwoławczego w przedmiocie obiektywnego charakteru odpowiedzialności administracyjnej, w tym przypadku odnośnie powstania

2 Dz. U. z 2001 r. Nr 100, poz. 1085 ze zm.

3 Dz. U. z 2003 r. Nr 177, poz. 1736 ze zm., akt utracił moc z dniem 30.04.2007 r. 
obowiązku poniesienia opłaty podwyższonej za korzystanie ze środowiska. Sąd I instancji wskazał przy tym, że okoliczności sprawy nie wskazywały na to, że brak pozwoleń zintegrowanych był spowodowany wyłącznie działaniem organów pozwoleniowych. Sąd I instancji podkreślił jednak, że co do zasady zawinienie takie nie byłoby przesłanką egzoneracyjną co do obowiązku poniesienia opłaty podwyższonej. Sąd I instancji wskazał, że w przedmiotowej sprawie przesłanka „braku pozwolenia" na eksploatację w I półroczu 2008 r. instalacji spółki skarżącej była spełniona. Sąd jednoznacznie podkreślił, że obowiązujące poprzednio pozwolenia sektorowe dla tych instalacji wygasły z dniem 31 grudnia 2006 r., to jest z chwilą upływu ustawowego terminu do uzyskania nowych pozwoleń zintegrowanych. W rezultacie sąd I instancji oddalił skargę spółki.

II. Naczelny Sąd Administracyjny oddalając skargę kasacyjną wniesioną przez spółkę odniósł się do tezy z uchwały składu siedmiu sędziów NSA z dnia 12 grudnia 2011 r. (sygn. akt II OPS 2/11): w sprawie o wymierzenie opłaty podwyższonej za korzystanie ze środowiska bez wymaganego pozwolenia lub innej decyzji, na podstawie art. 276 ust. 1 ustawy z dnia 27 kwietnia 2001 r. Prawo ochrony środowiska (Dz. U. z 2008 r. Nr 25, poz. 150 ze zm.), przyczyna braku pozwolenia może mieć znaczenie, jeżeli podmiot korzystajacy ze środowiska na podstawie wymaganego pozwolenia wystapił o wydanie pozwolenia na kolejny okres ${ }^{4}$. W tym kontekście NSA wskazał, że w przedmiotowej sprawie teza ta nie znajduje swego zastosowania z uwagi na fakt, że skarżąca spółka dotąd nie posiadała wymaganych pozwoleń zintegrowanych. W ocenie NSA należało podzielić stanowisko wyrażone $\mathrm{w}$ uchwale składu siedmiu sędziów, w myśl którego przyczyna braku pozwolenia nie ma znaczenia przy korzystaniu ze środowiska poprzez eksploatację instalacji bez pierwszego pozwolenia ( $\mathrm{w}$ tym przypadku - pozwolenia zintegrowanego). Według NSA jest bowiem oczywiste, co wystąpiło w stanie faktycznym i prawnym w tej sprawie, że przyczyny braku pozwolenia zintegrowanego przez podmioty korzystające ze środowiska nie mogą usprawiedliwiać rozpoczęcia przez nie-

4 ONSAiWSA z 2012 r., nr 2, poz. 22; dalej cyt.: uchwała 2/11. 
go danej działalności, ponieważ korzystałby z uprzywilejowanej sytuacji prawnej w zakresie ponoszenia opłat za korzystanie ze środowiska.

Jednocześnie w ocenie NSA nie ulegało wątpliwości, że skarżąca spółka nie posiadała wymaganego prawem od dnia 1 stycznia 2007 r. pozwolenia zintegrowanego, a pomimo tego świadomie rozpoczęła działalność gospodarczą łączącą się z eksploatacją określonych instalacji, co stanowiło przesłankę do wymierzenia opłaty podwyższonej, jak również stanowiło naruszenia art. 4 ust. 2 uPoś oraz zasady kompleksowości i zasady zapobiegania.

III. Na tle niniejszej sprawy, dotyczącej opłaty podwyższonej za korzystanie ze środowiska w I półroczu 2008 r. Ceramiki Budowlanej Sp. z o.o. w Krakowie bez wymaganych pozwoleń zintegrowanych, możliwe staje się prześledzenie wpływu uchwały składu siedmiu sędziów NSA z 12 grudnia 2011 r. na rozstrzygnięcie sądu administracyjnego konkretnego przypadku. Główna teza uchwały, stanowiąca interpretację przesłanki „braku wymaganego pozwolenia lub innej decyzji” z art. 276 ust. 1 uPoś została przytoczona powyżej. Uchwała 2/11 została podjęta przez skład siedmiu sędziów NSA na wniosek Rzecznika Praw Obywatelskich, który zwrócił się o wyjaśnienie przepisów prawnych, których stosowanie wywołało rozbieżności w orzecznictwie sądów administracyjnych co do tego czy $w$ sprawie dotyczacej wymierzenia podwyższonej opłaty za korzystanie ze środowiska bez uzyskania wymaganego pozwolenia (art. 276 ust. 1 [uPoś]) sam fakt korzystania ze środowiska bez pozwolenia stanowi wystarczająca przestankę wymierzenia tej opłaty, czy tė̇ organ administracji publicznej powinien badać również przyczyny braku pozwolenia?

Uzasadniając swój wniosek skierowany do NSA Rzecznik wskazał, iż w jego przekonaniu podmiot korzystający ze środowiska nie może zostać obciażony administracyjna odpowiedzialnościa za niesprawne funkcjonowanie administracji publicznej, zaś wykładnia art. 276 ust. 1 uPoś dopuszcza $w$ toku postępowania prowadzonego $w$ sprawie wymierzenia podwyższonej opłaty za korzystanie ze środowiska, badanie przyczyn, które spowodowaty, $\dot{z}$ e podmiot korzystajacy ze środowiska czyni to bez pozwolenia. 
Z kolei prokurator Prokuratury Generalnej stanął na odmiennym stanowisku, w myśl którego $w$ sprawie dotyczacej wymierzenia podwyższonej opłaty za korzystanie ze środowiska bez uzyskania wymaganego pozwolenia (art. 276 ust. 1 uPoś) sam fakt korzystania ze środowiska bez pozwolenia stanowi wystarczajaca przesłankę do wymierzenia tej opłaty przez organ administracji publicznej.

W uzasadnieniu uchwały 2/11 NSA dokonał podstawowego rozróżnienia na tle art. 276 ust. 1 uPoś, w którym to przepisie ustawodawca lakonicznie wskazał, że podmiot korzystający ze środowiska bez uzyskania wymaganego pozwolenia lub innej decyzji ponosi opłatę podwyższoną za korzystanie ze środowiska. W ocenie NSA można w tym zakresie wskazać na dwie sytuacje faktyczne podmiotu korzystającego ze środowiska:

1) korzystanie ze środowiska na podstawie wymaganego pozwolenia, gdy podmiot ten wystąpił o kolejne pozwolenie na kolejny okres, lecz pozwolenie takie nie zostało wydane przed upływem czasu, na jaki zostało wydane poprzednie pozwolenie;

2) rozpoczęcie korzystania ze środowiska bez wymaganego pozwolenia lub innej decyzji (jak należy przyjąć bez pierwszego pozwolenia).

W odniesieniu do drugiej sytuacji w uchwale 2/11 NSA zajął jednoznaczne stanowisko, w myśl którego w tym przypadku stosowanie art. 276 ust. 1 uPoś nie budzi wątpliwości. Należy więc przyjąć, że zdaniem NSA samo zaistnienie przesłanki „braku pozwolenia" jest wystarczające do powstania obowiązku poniesienia opłaty podwyższonej, a przyczyna braku pozwolenia nie będzie miała co do zasady znaczenia w tym zakresie. Tym samym NSA zawęził pole swoich rozważań do sytuacji pierwszej, przywołanej powyżej, gdy podmiot korzystający ze środowiska dysponował wymaganym pozwoleniem na czas oznaczony, a po upływie czasu, na jaki zostało wydane, nadal korzysta ze środowiska $w$ toku postępowania o wydanie wymaganego pozwolenia na kolejny okres. Ponadto NSA uznał, że celowe jest podjęcie analizy głównie konkretnej przyczyny braku pozwolenia, to jest przyczyny polegajacej na tym, ̇̇e właściwy organ prowadzi 4/2012 postępowanie $w$ sposób przewlekty, co powoduje, że uptywa okres, 
na jaki zostato wydane dotychczasowe pozwolenie, a pozwolenie na kolejny okres nie zostało wydane na skutek przewlekłego prowadzenia postępowania.

W tym więc granicach NSA w uchwale $2 / 11$ przyjął, że do przestanki „brak wymaganego pozwolenia” należy zastosować nie tylko wykładnię językowa, ale także wykładnię systemową i celowościową. Nie można bowiem z góry wykluczyć w każdej sytuacji, $i \dot{z}$ przyczyna braku wymaganego pozwolenia nie ma znaczenia. Stąd też zdaniem NSA w konkretnej sytuacji, w przypadku podmiotu korzystającego ze środowiska $w$ toku postępowania o wydanie wymaganego pozwolenia na kolejny okres, należy brać pod uwagę przy ocenie przesłanki „braku pozwolenia” z art. 276 ust. 1 uPoś w szczególności następujące okoliczności:

1) posiadanie $w$ poprzednim okresie przez podmiot korzystający ze środowiska pozwolenia na eksploatację instalacji w rozumieniu art. $180 \mathrm{w}$ związku z art. 181 uPoś;

2) termin wystąpienia $z$ wnioskiem o wydanie nowego pozwolenia oraz spełnienie wymagań przewidzianych dla wniosku, przebieg postępowania w tej sprawie, jak również to, czy nowe pozwolenie jest decyzją nieostateczną czy też ostateczną, lecz zaskarżoną do sądu administracyjnego;

3) brak naruszenia zasad ogólnych prawa ochrony środowiska (przede wszystkim zasady zrównoważonego rozwoju, zasady kompleksowości, zasady prewencji i przezorności oraz zasady zanieczyszczający płaci);

4) eksploatowanie instalacji zgodnie z zasadą najlepszych dostępnych technologii $\mathrm{w}$ rozumieniu art. 3 pkt 10 w związku z art. 207 uPoś.

Eksponując w omawianym zagadnieniu przyczynę braku pozwolenia związaną z działalnością organu NSA w uchwale 2/11 zaznaczył jednakże, iż podmiot korzystający ze środowiska składając wniosek o wydanie pozwolenia powinien uwzględnić okres konieczny do wydania pozwolenia, biorąc pod uwage wymagania stawiane przez ustawodawce eksploatacji danej instalacji, a w szczególności rodzaj $i$ skale prowadzonej $w$ niej działalności. NSA zarysował w ten sposób w kontekście przesłanki poniesie- 
nia opłaty podwyższonej zakres należytej staranności, wymaganej od podmiotu korzystającego ze środowiska chcącego uniknąć tej sankcji administracyjnej.

Dostrzegając trudności interpretacyjne art. 193 ust. 1, 3-4 uPoś (wygaśnięcie pozwolenia na wprowadzanie do środowiska substancji lub energii i stwierdzenie jego wygaśnięcia) i łącząc tę kwestię z przesłanką poniesienia opłaty podwyższonej, jaką jest „brak pozwolenia” NSA stwierdził, że spełnienie przez podmiot korzystający ze środowiska wskazanych powyżej wymagań odnośnie złożenia wniosku o nowe pozwolenie, które z przyczyn leżacych po stronie organu (bezczynność bądź przewlekłość postępowania) (...)nie zostato wydane przed uptywem terminu ważności pozwolenia dotychczasowego, skutkować będzie uzyskaniem przez ten podmiot szczególnego i jednocześnie korzystnego statusu prawnego $\mathrm{w}$ okresie między wygaśnięciem pozwolenia dotychczasowego, braku decyzji o stwierdzeniu jego wygaśnięcia i oczekiwaniem na pozwolenie nowe. Według NSA pomiędzy uptywem terminu ważności dotychczasowego pozwolenia a uzyskaniem nowego pozwolenia, opłata za korzystanie ze środowiska ponoszona powinna być $w$ wysokości dotychczasowej, a więc takiej, która obowiązywała w okresie ważności pozwolenia. Niedopuszczalne bowiem może być obciążanie podmiotu korzystającego ze środowiska ujemnymi konsekwencjami opieszatego lub przewlekłego prowadzenia postępowania administracyjnego $w$ postaci podwyższonych opłat za korzystanie ze środowiska.

IV. Zestawiając uchwałę 2/11 i wyrok w niniejszej sprawie można wskazać na kilka zasadniczych kwestii odnośnie opłaty podwyższonej z art. 276 ust. 1 uPoś, które nadal nasuwają szereg wątpliwości interpretacyjnych pomimo wysiłków podjętych przez NSA.

Rozpocząć przy tym należy od wyrażenia zasadniczo aprobaty dla przedstawionego $\mathrm{w}$ tych orzeczeniach stanowiska, iż odpowiedzialność administracyjna, do której elementów zalicza się konstrukcja opłaty podwyższonej, w warunkach demokratycznego państwa prawnego nie może mieć charakteru skrajnie zobiektywizowanego. Istnieją bowiem niewątpliwie sytuacje, w których egzekwowanie sankcji administracyjnoprawnej bez 4/2012 uwzględniania jakichkolwiek przyczyn leżących u podstaw za- 
istniałego naruszenia prawa administracyjnego byłoby nie do pogodzenia z ogólnymi zasadami prawa. Nawet więc zadanie publiczne, jakim jest ochrona środowiska zgodnie $\mathrm{z}$ zasadą zrównoważonego rozwoju, dla którego realizacji odpowiedzialność administracyjna ma olbrzymią wartość, nie może uzasadniać naruszania zaufania obywateli do państwa.

Na gruncie instytucji odpowiedzialności administracyjnej niezmierne istotne jest więc następujące pytanie: czy podmiot indywidualny zachowujący należytą staranność i działający w zaufaniu do organów administracji publicznej powinien ponosić konsekwencje naruszania prawa administracyjnego, gdy do zaistnienia tego naruszenia się nie przyczynił? Odpowiedź twierdząca jest niełatwa do pogodzenia z zasadami ogólnymi prawa. Z kolei odpowiedź przecząca otwiera drogę do szeregu dalszych pytań: co do przesłanek egzoneracyjnych, co do znaczenia winy i ewentualnych przesłanek ekskulpacyjnych, co do interpretacji pojęcia „należytej staranności”, co do ciężaru dowodu itd. Tego rodzaju elementy wprowadzane do konstrukcji odpowiedzialności administracyjnej mogą skutkować jej przekształceniem w swoistą hybrydę, co może zagrozić podstawowym celom tej instytucji prawnej oraz jej efektywnemu wykorzystywaniu w prawie ochrony środowiska.

W przypadku opłaty podwyższonej za korzystanie ze środowiska z art. 276 ust. 1 uPoś ustawodawca oparł realizację tej sankcji na jednej zasadniczej przesłance - korzystania ze środowiska „bez uzyskania wymaganego pozwolenia lub innej decyzji", nie precyzując bliżej jej zakresu. Niedookreślenie w tym przypadku nastręcza szeregu trudności w stosowaniu tego przepisu, a więc realizacji tej sankcji administracyjnoprawnej. Rzecznik Praw Obywatelskich słusznie więc wystąpił z wnioskiem $\mathrm{w}$ tej sprawie w trybie art. $264 \S 2 \mathrm{w}$ zW. $\mathrm{z}$ art. $15 \S 1$ pkt 2 PPSA $^{5}$, czego zwieńczeniem jest uchwała 2/11. Nasuwa się jednakże wątpliwość, czy w przypadku złożonego zagadnienia dotyczącego opłaty podwyższonej z uPoś RPO nie powinien był również wystąpić do właściwych organów z wnioskami o podjęcie

5 Ustawa z dnia 30 sierpnia 2002 r. Prawo o postępowaniu przed sądami administracyjnymi, tj. Dz. U. z 2012 r., poz. 270. 
inicjatywy ustawodawczej bądź o wydanie lub zmianę innych aktów prawnych w sprawach dotyczących wolności i praw człowieka i obywatela w trybie art. 16 ust. 2 ustawy z dnia 15 lipca 1987 r. o Rzeczniku Praw Obywatelskich ${ }^{6}$. Uchwała 2/11, jak już wspomniano wyżej, została zawężona zasadniczo do jednego rodzaju okoliczności faktycznych związanych z sytuacją podmiotu korzystającego ze środowiska i obowiązkiem poniesienia opłaty podwyższonej, przez co stosowanie art. 276 uPoś nadal nastręcza trudności. Wydaje się, że orzecznictwo NSA w bliższej perspektywie nie zdoła załatać luk wynikających z lakoniczności ustawodawcy w tym przedmiocie.

W uchwale 2/11 NSA przyjął jednoznaczny pogląd, że podmiot rozpoczynający korzystanie ze środowiska przy braku pierwszego pozwolenia winien ponieść opłatę podwyższoną z art. 276 ust. 1 uPoś niezależnie od przyczyny zaistnienia w tej sytuacji przesłanki „braku pozwolenia”. Okoliczności sprawy o sygn. II OSK 356/12 odsłoniły w interesujący sposób mankamenty takiego jednoznacznego podejścia do braku (używając pewnego skrótu myślowego) „pierwszego pozwolenia”. Możliwe jest bowiem rozróżnienie w tym wypadku przynajmniej dwóch sytuacji faktycznych:

1) podmiot korzystający ze środowiska nie miał dotąd w ogóle wymaganego pozwolenia, a rozpoczął działalność, dla której prowadzenia wymagane jest takie pozwolenie;

2) podmiot korzystający ze środowiska prowadził dotychczas działalność na podstawie pozwolenia jednego rodzaju, zaś w międzyczasie na skutek zmiany prawa pozwolenie to wygasło zanim podmiot ten uzyskał nowe pozwolenie innego rodzaju.

O ile w pierwszym przypadku zgodzić należy się co do zasady ze stanowiskiem NSA wyrażonym w uzasadnieniu wyroku w sprawie o sygn. II OSK 356/12, że przyczyny braku pozwolenia zintegrowanego przez podmioty korzystajace ze środowiska nie moga usprawiedliwiać rozpoczęcia przez niego danej działalności, poniewaz korzystałby z uprzywilejowanej sytuacji prawnej $w$ za- 
kresie ponoszenia opłat za korzystanie ze środowiska, o tyle druga sytuacja nasuwa więcej wątpliwości. W drugiej sytuacji bowiem podmiot korzystający ze środowiska działał zgodnie z obowiązującym prawem - uzyskał wymaganą akceptację ze strony organu dla swojej działalności i mógł był oczekiwać, że w okresie obowiązywania pozwolenia jego sytuacja prawna będzie podlegała zmianom wyłącznie w sposób zapewniający poszanowanie zasady proporcjonalności (art. 31 ust. 3 Konstytucji ${ }^{7}$ ) oraz zasady pewności prawa (np. odpowiednie przepisy intertemporalne).

Fakt, że podmiot korzystający ze środowiska w tej drugiej sytuacji działa w zaufaniu do władzy publicznej, w uprawniony sposób licząc na przewidywalność prawa i względną stabilizację stosunków prawnych oraz zachowując należytą staranność, predestynuje go do innego traktowania aniżeli podmiot świadomie naruszający prawo ochrony środowiska. Stąd też co do zasady zbieg zagadnienia opłaty podwyższonej za korzystanie ze środowiska i zmiany stanu prawnego odnośnie pozwoleń powinien zostać uznany za sytuację inną aniżeli zwykły „brak pierwszego pozwolenia".

W przedmiotowej sprawie - II OSK 356/12 - taka właśnie sytuacja została ustalona. Skarżąca spółka wskazywała bowiem, że pierwotnie uzyskała pozwolenia sektorowe na wprowadzanie do środowiska substancji lub energii. Spółka nie kwestionowała, jak się wydaje, obowiązku uzyskania do 31 grudnia 2006 r. nowych pozwoleń zintegrowanych, ani braku tych pozwoleń w analizowanym okresie - I półrocza 2008 r. W widoczny jednak sposób spółka podjęła próbę przesunięcia problemu z sytuacji „braku pierwszego pozwolenia” na sytuację drugą zmiany stanu prawnego w okresie dysponowania pozwoleniami sektorowymi, polegającą na obowiązku uzyskania nowego pozwolenia innego rodzaju. Taktyka ta miała służyć zwiększeniu szans na uzyskanie ochrony prawnej - takiej jak określona w uchwale 2/11 ochrona dla podmiotu korzystającego ze środowiska znajdującego się $\mathrm{w}$ trakcie oczekiwania na kolejne pozwolenie tego samego rodzaju - czyli obowiązku uiszczania

7 Konstytucja Rzeczypospolitej Polskiej z dnia 2 kwietnia 1997 r., Dz. U. z 1997 r. Nr 78, poz. 483 ze zm. 
tylko „zwykłej” opłaty za korzystanie ze środowiska w okresie I półrocza 2008 r., a nie opłaty podwyższonej.

Czy taka taktyka skarżącej spółki miała szanse przynieść oczekiwane rezultaty? Analiza tej kwestii ułatwi zobrazowanie oddziaływania uchwały $2 / 11 \mathrm{w}$ konkretnych sprawach. Pierwsze pytanie, jakie można postawić to pytanie o to jak teoretycznie powinno przedstawiać się procedowanie w przypadku podniesienia argumentu o zmianie prawa przez skarżącą spółkę. Wydaje się, że pierwszoplanową kwestią będzie w takim przypadku analiza prawa dotychczasowego i prawa nowego oraz ustalenie przepisów intertemporalnych. Następnie przyjęte przez ustawodawcę rozwiązania należy ocenić w świetle zasad ogólnych prawa, w tym zwłaszcza zasady pewności prawa, niedziałania prawa wstecz oraz ochrony praw nabytych. Brak przepisów przejściowych, zbyt krótki okres na dostosowanie się do prawa nowego i tym podobne rozwiązania mogą być w określonych sytuacjach nie do pogodzenia z zasadami ogólnymi prawa. Tego rodzaju luki musiałyby zostać wypełnione przez sądy administracyjne $\mathrm{w}$ procesie stosowania prawa. Brak odpowiednich przepisów przejściowych $\mathrm{w}$ przypadku pozwoleń zintegrowanych wpływać musiałby bezpośrednio na powiązany z tą instytucją prawną obowiązek poniesienia opłaty podwyższonej za korzystanie ze środowiska przy braku wymaganych pozwoleń. Skutkowałoby to przyznaniem ochrony prawnej w postaci ustalenia obowiązku poniesienia tylko opłaty „zwykłej”. W sprawie II OSK 356/12 takie ustalenia zakończyłyby procedowanie z korzyścią dla spółki skarżącej, bez konieczności analizowania dalszych zagadnień wynikających z uchwały 2/11.

W sprawie II OSK 356/12 organy i sądy administracyjne dokonały odpowiednich analiz odnośnie przepisów przejściowych dotyczących obowiązku uzyskania pozwoleń zintegrowanych dla instalacji takich, jakie eksploatowała skarżąca spółka. Należy uznać, że ustawodawca $\mathrm{w}$ tym przypadku wprowadził co do zasady przepisy, których zgodność z zasadami ogólnymi prawa nie wzbudza większych wątpliwości. Ustawodawca pozostawił w tym przypadku wystarczająco długi okres dostosowawczy (pięć lat) i skarżąca spółka nie mogłaby przekonująco wykazywać, że tą zmianą prawa została zaskoczona. 
Nasuwa się więc kolejne pytanie odnośnie tego, czy podmiot korzystający ze środowiska w takich okolicznościach może jeszcze mieć szansę na uzyskanie ochrony prawnej w świetle uchwały 2/11. Hipotetycznie rzecz ujmując, można przyjąć, że nadal istniałyby takie szanse. Na tym kolejnym etapie (po weryfikacji prawa intertemporalnego) należy ocenić okoliczności faktyczne sprawy przez pryzmat swoistego testu należytej staranności podmiotu korzystającego ze środowiska, wypracowanego przez NSA w tej uchwale. Trzeba przy tym jeszcze raz zaznaczyć, że przypadek zmiany prawa nie powinien być traktowany tak samo jak sytuacja braku „pierwszego pozwolenia” (co opisano już powyżej). Jest to sytuacja zdecydowanie bardziej zbliżona do oczekiwania na kolejne pozwolenie - tu także podmiot korzystający ze środowiska rozpoczął swoje działanie legalnie - to jest na podstawie ważnego pozwolenia, co uległo zmianie przede wszystkim na skutek nowego prawa, a więc nie jest to od początku świadome ignorowanie obowiązujących przepisów prawa ochrony środowiska.

Dołożenie należytej staranności przez podmiot korzystający ze środowiska w sytuacji zmiany prawa (zachowanie terminów, prawidłowy wniosek, nienaruszanie zasad prawa ochrony środowiska itd.) powinno przynieść taki sam skutek, jak ten dopuszczony przez NSA w składzie siedmiu sędziów w uchwale $2 / 11$ - to jest obowiązek poniesienia w okresie przejściowym jedynie „zwykłej” opłaty za korzystanie ze środowiska. Całkowite pozbawienie zachowującego $\mathrm{w}$ takiej sytuacji należytą staranność podmiotu korzystającego ze środowiska ochrony prawnej wyłącznie z tego powodu, że dotychczasowe pozwolenie było sektorowe, a kolejne winno być pozwoleniem zintegrowanym naruszałoby zasadę równości wobec prawa. Przy milczeniu ustawodawcy wszelkie wątpliwości powinny być rozstrzygnięte na korzyść podmiotu indywidualnego, nawet w przypadku niepokrywającego się zakresu tych dwóch pozwoleń. Odmienne stanowisko byłoby równoznaczne z przerzuceniem całego ryzyka zmian w prawie oraz luk prawnych na podmiot indywidualny, co naruszałoby art. 31 ust. 3 Konstytucji, wobec którego to rozwiązania NSA właśnie w swojej uchwale $2 / 11$ wyraził przecież wyraźny sprzeciw. 
Mając więc powyższe na względnie należy zastanowić się, jakie wnioski płyną z oceny zachowania skarżącej spółki w sprawie II OSK 356/12 w świetle testu należytej staranności z uchwały $2 / 11$. Ustalone przez organy i oba sądy administracyjne okoliczności tej sprawy (w znacznej mierze niekwestionowane przez skarżącą spółkę) przemawiają za przyjęciem, że spółka ta postępowała w sposób niespełniający wypracowany przez NSA w uchwale 2/11 wzorzec należytej staranności głównie, jak się wydaje, odnośnie terminów oraz wymogu kompletności wniosków o pozwolenia zintegrowane. Z tego więc powodu spółka ta nie powinna była otrzymać ochrony prawnej określonej uchwała 2/11 i ochrona ta nie została jej przez NSA przyznana (jakkolwiek sąd kierował się tu innymi względami, aniżeli opisane powyżej).

V. Podsumowując więc omawiane zagadnienie wpływu zmiany prawa na obowiązek poniesienia opłaty podwyższonej za korzystanie ze środowiska w świetle wyroku II OSK 356/12 oraz uchwały $2 / 11$, należy w pierwszej kolejności wskazać, że wprawdzie uchwała składu siedmiu sędziów NSA stanowi ważny precedens $\mathrm{w}$ analizowanej problematyce, to jednak można zarzucić jej kilka braków. Przede wszystkim niezrozumiałe jest zawężenie przedstawionych w uchwale ustaleń, co nastręczyło trudności właśnie w okolicznościach faktycznych sprawy II OSK 356/12. Z tego powodu problem w interpretacji przesłanki „braku pozwolenia” z art. 276 ust. 1 uPoś nadal nabrzmiewa, nie tylko w odniesieniu do zmiany prawa ochrony środowiska polegającej na wprowadzeniu nowego pozwolenia, jak to miało miejsce $\mathrm{w}$ tym przypadku.

Kolejnym bowiem obszarem pominiętym w uchwale 2/11 jest zagadnienie stwierdzenia nieważności pozwolenia na wprowadzanie do środowiska substancji lub energii, także przecież łączącego się z powstaniem obowiązku poniesienia opłaty podwyższonej. Przesłanka „braku pozwolenia” będzie również przy takiej mającej skutek ex tunc decyzji spełniona, co może nieść ze sobą dotkliwe skutki finansowe dla podmiotu korzystającego ze środowiska, który polegał na domniemaniu ważności swojego pozwolenia. Takie sprawy są już rozstrzygane przez sądy admi4/2012 nistracyjne. Warto tu wskazać na odważne (i, zdaniem glosator- 
ki - prawidłowe) stanowisko zajęte przez WSA w Bydgoszczy w wyroku z dnia 14 lutego 2012 sygn. akt II SA/Bd 1226/118. Sąd ten stwierdził, iż przepisy art. 276 ust. 1 i art. 292 ustawy - Prawo ochrony środowiska nie uprawniaja do wymierzenia opłaty podwyższonej $w$ przypadku stwierdzenia nieważności decyzji udzielajacej pozwolenia wodnoprawnego, jeżeli $w$ okresie obowiąywania tego pozwolenia podmiot korzystał ze środowiska na jego podstawie i uiszczał opłaty za korzystanie z niego $w$ wysokości zgodnej z obowiazujacymi $w$ tym czasie przepisami prawa. Zdaniem Sadu stwierdzenie przez organ nieważności udzielonego wcześniej stronie pozwolenia wodnoprawnego nie może prowadzić do przyjęcia całkowitej fikcji prawnej, $i \dot{z}$ dany podmiot korzystat ze środowiska bez uzyskania wymaganego pozwolenia. Takie pozwolenie bowiem podmiot korzystajacy ze środowiska obiektywnie uzyskat, z tym że zostało ono następnie na skutek decyzji organu wyeliminowane z obrotu prawnego. Nie można więc postawić temu podmiotowi zarzutu bezprawnego korzystania $w$ tym czasie ze środowiska, a taki byłby konieczny dla zastosowania przepisu o charakterze represyjnym, którym jest wymierzenie opłaty podwyższonej.

Wydaje się, że WSA w Bydgoszczy zmierzał w tym wypadku w podobnym kierunku co NSA w uchwale $2 / 11$ - to jest objęcia ochroną prawną podmiotu korzystającego ze środowiska w związku z obowiązkiem poniesienia opłaty podwyższonej przy „braku pozwolenia” z przyczyn niezależnych od tego podmiotu, co należy ocenić aprobująco. Szkoda więc, że przy okazji podejmowania uchwały $2 / 11$ także i to zagadnienie nie zostało poddane bliższej analizie. Podobnie jak ma to miejsce w przypadku kwestii zbiegu wydania decyzji ze skutkiem ex nunc dotyczących pozwoleń (np. cofnięcie pozwolenia, czy też uchylenie pozwolenia w trybie art. $145 \mathrm{kpa}$ ) z powstaniem obowiązku poniesienia opłaty podwyższonej. W tym przypadku również będzie często pojawiał się okres przejściowy, z którym może łączyć się opłata podwyższona. Jak w takim przypadku oceniać sytuację prawną podmiotu korzystającego ze środowiska, skoro część przesłanek np. cofnięcia pozwolenia na wprowadzanie do

8 Wyrok nieprawomocny, http://orzeczenia.nsa.gov.pl. 
środowiska substancji lub energii zaistnieje w przyczyn niezależnych od zachowanie tego podmiotu. Przykładem może tu być choćby art. 195 ust. 1 pkt 2 uPoś, w myśl którego pozwolenie może zostać cofnięte lub ograniczone bez odszkodowania, jeżeli przepisy dotyczące ochrony środowiska zmieniły się w stopniu uniemożliwiającym emisję na warunkach określonych w pozwoleniu. Wydaje się, że wyciągnięcie pełnych konsekwencji $\mathrm{z}$ art. 276 ust. 1 uPoś wobec podmiotu nie dysponującego już pozwoleniem $\mathrm{z}$ tego powodu $\mathrm{w}$ zaistniałym następnie okresie przejściowym byłoby również trudne do pogodzenia z zasadą demokratycznego państwa prawnego.

Biorąc pod uwagę powyższe stwierdzenia można wskazać, że na tle problematyki art. 276 ust. 1 uPoś i instrumentu odpowiedzialności administracyjnej, jakim jest opłata podwyższona za korzystanie ze środowiska, istnieje nadal szereg wątpliwości interpretacyjnych, które w szeregu wypadków można zakwalifikować jako luki w prawie. W swojej uchwale 2/11 NSA starał się wyjść naprzeciw tym trudnościom, jednakże nie udało się to w pełni. Co więcej, wydaje się, że usunięcie części z tych luk za pomoca wykładni nie jest możliwe. Z tego względu, zamiast działalności uchwałodawczej NSA powinna mieć miejsce interwencja ustawodawcy, który całą konstrukcję opłaty podwyższonej winien poddać szerokiemu oglądowi i uporządkować. W stanie obecnym można jednoznacznie wskazać, że niespójności w konstrukcji opłaty podwyższonej w części przypadków należałoby uznać za naruszające konstytucyjną zasadę demokratycznego państwa prawnego, gdyż godzą w niedopuszczalny sposób w prawa i wolności człowieka i obywatela. Stan ten nie sprzyja przy tym ochronie środowiska, ponieważ niespójności te utrudniają jednocześnie egzekwowanie prawa ochrony środowiska, co osłabia jego skuteczność.

Jak na razie więc, przy braku działania ustawodawcy, zadanie pogodzenia interesu publicznego $\mathrm{w}$ postaci ochrony środowiska z należną ochroną prawną podmiotów indywidualnych w tym zakresie spoczywa wyłącznie na sądach administracyjnych. Sprawa II OSK 356/12 pozwoliła naszkicować skalę trudności wiążących się z tym zadaniem, istniejących pomimo 4/2012 precedensowej uchwały $2 / 11$. Wprawdzie wyrok w sprawie II 
OSK 356/12 należy uznać za prawidłowy z uwagi na stan faktyczny, to jednak nie sposób w pełni zaakceptować argumentów co do prawa przedstawionych $\mathrm{w}$ jego uzasadnieniu. W szczególności nie można zgodzić się ze zrównaniem sytuacji braku „pierwszego pozwolenia” z sytuacją zmiany prawa polegającej na obowiązku uzyskania nowego pozwolenia innego rodzaju przez podmiot posiadający już pozwolenie sektorowe. W rezultacie należy wskazać, że prawidłowy tok postępowania wymagał przeprowadzenia oceny pierwszoplanowo co do przepisów intertemporalnych, a następnie zweryfikowania przyczyn zaistnienia przesłanki „braku pozwolenia” w sposób taki, jak dla sytuacji oczekiwania na nowe pozwolenie, gdy upłynął już termin ważności pozwolenia dotychczasowego. Fakt, iż chodziło o dwa różne pozwolenia: sektorowe i zintegrowane, nie może być wykorzystywany do wsparcia fikcji prawnej, iż taki podmiot nigdy dotąd żadnego pozwolenia na wprowadzanie do środowiska substancji lub energii nie miał, zwłaszcza że w oparciu o art. 276 ust. 1 uPoś nie sposób tego zawężonego podejścia podtrzymać jako wyłącznego usprawiedliwienia dla zastosowania finansowej sankcji administracyjnej. Skoro bowiem NSA uznał, że w zakresie przesłanki „braku pozwolenia” nie mieści się brak kolejnego pozwolenia tego samego rodzaju, to z równym powodzeniem można też przyjąć, że nie mieści się tu brak pozwolenia nowego rodzaju, gdy podmiot dysponował w poprzednim stanie prawnym pozwoleniem innego rodzaju wymaganym dla tej samej działalności.

Takie konsekwentne podejście zapewniłoby podmiotowi indywidualnemu ochronę prawną, gdyby okoliczności faktyczne w sprawie II OSK 356/12 były inne (czyli dające się zakwalifikować jako spełnienie testu należytej staranności), czyniąc zadość zasadzie równości wobec prawa. Natomiast nie w pełni spójne stanowisko sądu administracyjnego przedstawione w uzasadnieniu do tego wyroku obarczone jest ryzykiem osłabienia ochrony prawnej podmiotu indywidualnego, godzącym w przysługujące temu podmiotowi konstytucyjne gwarancje. 